REGARDS

SUR L'ECONOMIE ALLEMANDE

BULLETIN ECONOMIQUE DU CIRAC

\section{Regards sur l'économie allemande}

Bulletin économique du CIRAC

$67 \mid 2004$

Varia

\title{
Innovation et croissance
}

GRIES Thomas et al. (eds), Neue Wachstums- und Innovationspolitik in Deutschland und Europa

\section{(2) OpenEdition}

Journals

Édition électronique

URL : http://journals.openedition.org/rea/3824

DOI : $10.4000 /$ rea.3824

ISBN : 978-2-8218-0830-0

ISSN : 1965-0787

Éditeur

CIRAC

Édition imprimée

Date de publication : 1 juillet 2004

ISSN : 1156-8992

Référence électronique

"Innovation et croissance », Regards sur l'économie allemande [En ligne], 67 | juillet 2004, mis en ligne le 08 octobre 2009, consulté le 22 septembre 2020. URL : http://journals.openedition.org/rea/3824 ; DOI : https://doi.org/10.4000/rea.3824

Ce document a été généré automatiquement le 22 septembre 2020.

(c) CIRAC 


\section{Innovation et croissance}

GRIES Thomas et al. (eds), Neue Wachstums- und Innovationspolitik in Deutschland und Europa

\section{RÉFÉRENCE}

GRIES Thomas et al. (eds), Neue Wachstums- und Innovationspolitik in Deutschland und Europa, Coll. Wirtschaftswissenschaftliche Beiträge, vol. 189, Physica-Verlag, Heidelberg, 2003, 292 p.

1 Les contributions rassemblées dans ce recueil analysent l'évolution de la croissance dans les Etats membres, les USA et le Japon afin de comprendre les mécanismes structurels qui freinent ou au contraire dynamisent la compétitivité de l'Allemagne et des autres pays dans une économie mondiale où la spécialisation s'accentue. (IB) 